\title{
Family Group Conferencing
}

Family group conferencing (FGC) is an inclusive and informal process of making and implementing a plan that safeguards children, young persons, and adults. At the center of the planning is the "family group," encompassing the immediate family as well as their relatives, friends, and other informal ties. Supporting the process are the involved community organizations and public agencies. The model's origins, legalization, process, dissemination, and outcomes all reflect a culturally based approach to resolving interpersonal violence and other relationship concerns.

FGC's deliberative processes are rooted in South Pacific practices and evident in many Native cultures. In 1989, the model was first legislated in New Zealand following protests by its Indigenous peoples against Eurocentric approaches to child welfare and youth justice. The legislation emphasized the family group's responsibility for their young relatives, children's safety and rights, the family's culture, and community-government partnerships.

The New Zealand model of FGC has six key features that emphasize the centrality of the family group. First, the conference is organized by an independent FGC coordinator who is not the family's worker. This decreases role confusion and keeps the coordinator focused on creating a safe and effective process. Second, the coordinator invites and prepares the participants. This makes it possible to explain the purpose and process, assess for safety, and develop sound conference arrangements. Third, the conference begins with a welcome, overview of the process, and information sharing. Fourth, the family group has its private time in which to develop a plan without the service providers present. Fifth, the service providers are invited back to review and approve the plan and authorize agency resources. And sixth, the plan is implemented, and the family group can be reconvened to address emerging issues.

Today, FGC has been adopted in countries from all continents and utilized in diverse cultures to address such issues as child protection, youth and adult offending, school bullying, domestic violence, mental health, and disabilities. As an imported model, it has been variously renamed and its practices reshaped. Nevertheless, FGC remains distinct from court procedures because of its informality, from mediation because of its group approach, and from family therapy because of its decision-making focus.

The available studies report promising results. In general, FGC is carried out without violence and leads to mutually agreed-upon plans. The plans keep children and youth connected with their family group and cultural heritage without endangering them in the home, school, or community. Widening the circle of support and participation in the process helps in healing the emotional harm caused by interpersonal violence and creating lasting solutions.

Joan Pennell

See also Peacemaking Circles; Restorative Justice

\section{Further Readings}

Hudson, J., Morris, A., Maxwell, G., \& Galaway, B. (Eds.). (1996). Family group conferences: Perspectives on policy and practice. Monsey, NY: Willow Tree Press.

Pennell, J., \& Anderson, G. (Eds.). (2005). Widening the circle: The practice and evaluation of family group conferencing with children, youths, and their families. Washington, DC: NASW Press.

Strang, H., \& Braithwaite, J. (Eds.). (2002). Restorative justice and family violence. New York: Cambridge University Press.

Source: Renzetti, C. M., \& Edleson, J. L. (2008). Encyclopedia of interpersonal violence (2 vols.). Thousand Oaks, CA: Sage. Copyright (C) 2008 by SAGE Publications. All rights reserved. No part may be reproduced or utilized in any form or by any means, electronic or mechanical, including photocopying, recording, or by any information storage and retrieval system, without permission in writing from the publisher. 